\title{
Down River Road in contemporary Kenyan popular fiction Sam Dennis Otieno
}

The understanding of the contemporary Kenyan society in popular fiction during the post-Moi years was largely made possible by the Kwani? literary journals. The influence of Kwani? on the Kenyan literary terrain has, however, been marred by a decline in its literary activities as has been recorded by Carey Baraka in the Johannesburg Review of Books. This notwithstanding, literary activities within Kenya still continue to thrive as is evident in the founding of a new literary magazine called Down River Road (DRR) which also seems to follow the path set out by its predecessor, Kwani? in not conforming to artistic and generic boundaries.

In the "About" section on the DRR website, the editors explain that the magazine identifies as an "[...] online and print journal that publishes fiction, nonfiction, poetry and ideas" and is interested in "[...] the margins, in the shifting centres and the new spaces that exist in what we've come to call the alternative". The identity of DRR also embodies its philosophy which seeks to imagine the world "here, in the right now, in the ongoing, in this perpetual machine we call enlightenment [...]": a philosophy that seeks to creatively represent the world in the present time. This 'here' and the 'right now' of the DRR philosophy is reflected in its publications which represent human conditions in the contemporary Kenyan society. For DRR, the evolution of society demands new ways of chronicling it and the cultures within while still maintaining a fidelity to artistic demands. These new ways of chronicling the contemporary Kenyan society are embodied in the publications by DRR in terms of their concerns and even linguistic choices. So far, DRR has published two issues: "Place" in 2019 and "Ritual" in 2020, a reading of which elucidates both the identity and the philosophy of the literary magazine.

In "Place", narratives of being in the contemporary Kenyan society are explored. This is made possible by the curation of stories and poems that interrogate the theme of place and how characters strive to make meaning of their existence in various places, be they physical or psychological. In its engagement with the subject of place, the stories in this literary magazine also examine the fluidity of identity as a means of survival in the contemporary urban and rural Kenyan societies. The magazine further adopts new ways of storytelling such as the flash fiction genre through which the stories explore the human condition in the contemporary society. "Ritual" contains stories and poems that examine the rituals governing human existence. The subjects addressed range from understandings of grief to reflections on memory and even rituals of everyday life. The rituals of everyday life are represented in a depiction of the daily hustles and bustles of life in the city and stories that depict issues on body consciousness among the youth. "Ritual" also abides by the magazine's philosophy of imagining the 'ongoing' in the here and now through visual narratives, which are increasingly becoming a preferred way of storytelling in contemporary societies. The visual narratives in "Ritual" include works of photography and colour paintings which visually represent the rituals of the human condition in urban and rural settings.

The inclusion of the genre of flash fiction and visual narratives in the DRR literary magazines contributes to a newness in ways of storytelling in contemporary societies. These ways of storytelling still stand in the margins of literary criticism and warrant a critical reception as society evolves and new ways of chronicling it emerge. The language and structures in the stories and poems contained in these magazines are actual reflections of breaching artistic and genre-specific boundaries. Nevertheless, the magazines do not ignore literary merits in their pursuit of a literary revolution in contemporary Kenyan society. Even within the margins and the shifting centres, the contents of the DRR literary magazines still embody literary standards of creativity and intellectual rigour that can actually contribute not just to the vibrancy of the Kenyan literary scene but also to meaningful knowledge production on contemporary Kenyan literature.

Sam Denis Otieno is a PhD candidate in Literature at the University of Nairobi, Nairobi, Kenya. His research interests include Kenyan popular fiction, contemporary East African life narratives, and literary visualities.

Email: samdennis951@gmail.com

(iD https://orcid.org/0000-0001-9022-737X

Dol: https://doi.org/10.17159/tt.158il.9481 
As DRR continues to blaze its trail in contemporary Kenyan popular literature, other literary magazines such as Enkare Review and Jalada Africa continue to contribute to literary imaginations of the contemporary society, although from the margins. Both magazines utilise a model similar to that of DRR - a model that seeks to curate narratives of the contemporary society without being beholden to the demands of artistic and generic boundaries. Whereas DRR exists both online and in print, Jalada Africa and Enkare Review largely represent the contemporary society from the digital space. The use of the digital space as a means of literary production and artistic expression is also gaining traction as a new way of perceiving the world through literature. This is seen in critical inquiries by scholars of digital humanities who are interested in the ways through which the digital world has influenced ways in which researchers interact with the world. The vibrancy of the Kenyan literary space is thus kept by these journals which continue to push the boundaries of literary production in Kenya, albeit from the margins.

Beyond critical inquiry into the place of DRR within scholarship on digital humanities, these literary magazines are also potential sites for postmodernist readings of contemporary Kenyan popular fiction. The presence of visual narratives in these magazines, as new forms of texts in literature, invite ekphrastic interpretations to the texts as espoused by Ronja Bodola and Guido Isekenmeir in Literary Visualities (2017). Ekphrastic interpretations will subject visual to the verbal and, in doing so, broaden the boundaries of literary interpretation in the evaluation of these new/unorthodox genres of literature that are quickly gaining ground in Kenyan literary production.

While I have largely focused on DRR as the newest literary establishment in Kenya in this essay, the presence of Jalada Africa and Enkare Review continue to shape our understanding of contemporary Kenyan popular literature. In their early stages, the DRR literary magazines offer literary critics of East African literature fresh perspectives of interrogating emergent forms of literature from Kenya and their place within regional literature as well as African and global literature in the $21^{\text {st }}$ century.

\section{Works Cited}

Baraka, Carey. "Intimations of an Ending-Carey Baraka on the Unspoken Demise of Kwani?, and the Death of a Dream." The Johannesburg Review of Books. 27 Aug. 2020. http://johannesburgreviewofbooks.com/2020/08/27/intimations-of-an-endingcarey-baraka-on-the-unspoken-demise-of-kwani-and-the-death-of-a-dream/.

Bodola, Ronja \& Guido Isekenmeier, eds. Literary Visualities: Visual Descriptions, Readerly Visualisations, Textual Visibilities. De Gruyter, 2017. 